\title{
Estrutura Social e Crise Política no Brasil
}

\author{
Sérgio Costa
}

Freie Universität Berlin, Berlim, Alemanha. E-mail: sergio.costa@fu-berlin.de

\begin{abstract}
T um artigo escrito durante um dos momentos mais agudos da crise enfrentada pelo Brasil no ano de 2016, o economista SaadFilho (2016), da Universidade de Londres, afirmava que o Brasil, àquela altura, era "a terra dos sonhos para cientistas sociais [e] um pesadelo para todos os demais". ${ }^{1}$ Ele tinha razão. A crise travou as instituições, fez o PIB despencar de um crescimento anual de 7,6\% em 2010 para 0,1\% em 2014, menos 3,8\% em 2015, menos 3,6\% em 2016, e 1\% em 2017, consumiu os empregos formais e endividou as famílias. O impeachment da Presidente Dilma Rousseff, sacramentado em agosto de 2016 pelo Senado Federal, em nada contribuiu para reverter a crise, já que o então vice-presidente empossado como presidente, Michel Temer, acuado pelas denúncias de corrupção, esteve longe de lograr algum avanço no sentido de superar as crises econômica e política. A eleição, em outubro de 2018, do militar reformado e político radical de direita, Jair Bolsonaro, tampouco parece ser um bom caminho para o fim dos impasses e a reconciliação do país.
\end{abstract}

A crise alimentou a curiosidade dos cientistas sociais interessados em desvendar a razão de tamanha polarização política num país que, apesar de sua história extremamente violenta, realizou suas principais transições, incluindo-se a independência, a abolição da escravatura e a proclamação da república no século XIX, bem como a superação das ditaduras do século XX, não atráves de revoluções, mas de acordos entre DADOS - Revista de Ciências Sociais, Rio de Janeiro, vol. 61, n-4, 2018, pp. 499 a 533. 
as elites. Como explicar que, a despeito do consenso de fundo vigente, segundo o qual se aceita o combate à pobreza desde que os ganhos dos mais ricos não sejam afetados, o país tenha se dividido em dois blocos irreconcialiáveis de defensores e contrários aos governos comandados pelo Partido dos Trabalhadores (PT)?

Este ensaio é uma tentativa de explicar esta situação paradoxal valendo-se da análise de classes. Para tanto, recupera-se inicialmente alguns dos argumentos centrais dos que defendem a atualidade do conceito de classes no âmbito do capitalismo tardio. Em seguida, busca-se entender as mudanças recentes na estrutura social brasileira, para depois interpretar a crise política brasileira contemporânea à luz da análise da estrutura social desenvolvida.

\section{MARCO ANALÍTICO: REINTERPRETANDO WEBER SEM ABANDONAR MARX}

\section{Classes e Estratos Importam}

Durante a segunda metade do século $X X$, os estudos sobre estratificação social fundamentados, teoricamente, no funcionalismo conquistaram a hegemonia no campo dos estudos sociológicos sobre desigualdade social, ao menos no mundo anglo-saxão. De acordo com esta perspectiva, a desigualdade é funcional e necessária para as sociedades na medida em que aqueles que desenvolvem atividades socialmente mais relevantes e/ ou que apresentam um nível mais elevado de "treino ou talento" devem ser recompensados com mais recursos (Davis e Moore, 1944:243). Ainda que tenham em comum o fato de se oporem frontalmente à leitura funcionalista, as pesquisas sobre desigualdade que seguem, respectivamente, a tradição weberiana e a tradição marxista desenvolveram-se no pós-guerra de maneira independente e, só mais recentemente, os esforços de combinar estas duas tradições ganharam visibilidade e expressão acadêmica mais consideráveis.

As abordagens marxistas, em suas diversas variantes, apresentam como premissas comuns ao menos dois elementos, quais sejam: i) definem a relação capital/trabalho como estruturante das classes sociais, na medida em que os que possuem os meios de produção constituem a classe proprietária ou dominante, e os que vendem sua força de trabalho formam a classe trabalhadora ou dominada; ii) estabelecem um vínculo lógico necessário entre pertença estrutural de classe e escolhas culturais e políticas. Isto significa que, se a classe trabalhadora não 
apresenta o comportamento cultural e político que lhe cabe por força da inserção estrutural, isto se deve a desvios ideológicos (Wright, 1985).

As abordagens que partem de Weber apresentam em comum com os marxistas o fato de afirmarem que as classes sociais constituem um princípio conformador da estrutura social das sociedades modernas. Discordam, contudo, dos marxistas ao questionar o vínculo necessário entre a classe, entendida como "situação de classe", isto é, como a inserção material na estrutura social, e formas de ação e comportamento, seja no plano cultural ou político. Portanto, a tradição weberiana nega qualquer determinismo político que decorra da situação ou posição de classe. Nos dizeres do próprio Weber, pessoas que pertencem a uma mesma classe podem até agir politicamente, em circunstâncias determinadas, em favor de seus interesses comuns como uma comunidade de interesses, "mas não tem que ser assim; de qualquer forma classe não é uma comunidade [Gemeinschaft] e tratar classes conceitualmente como sinônimo de comunidades leva a distorções" (Weber, 1956 [1922]:533). Por outro lado, na medida em que a classe é definida pelo compartilhamento por um grupo de pessoas de um "fator determinante específico de suas chances vitais" (ibidem:531) qual seja, o lugar ocupado nas hierarquias de distribuição de riqueza, e não mais exclusivamente pela propriedade ou não de meios de produção, as posições possíveis na estrutura social se multiplicam para além da classe proprietária e trabalhadora conforme concebido no marxismo.

Além disso, conforme mostra Parkin $(1972,1974)$ há outra razão que, conforme as interpretações neoweberianas, justifica a identificação de posições na estrutura social que vão além da dualidade proprietários/trabalhadores. Trata-se da diversidade das estratégias de "encerramento social" (social closure) próprias ao processo de formação de classes:

"Por encerramento social, Weber entende o processo através do qual coletividades buscam maximizar ganhos restringindo o acesso a vantagens e oportunidades a um limitado círculo de beneficiários. Isto implica a especificação de certos atributos sociais ou físicos como justificativa para a exclusão social" (ibidem, 1974:3).

Na medida em que as estratégias de social closure vão muito além da luta pela detenção dos meios de produção, se ampliam também as posições de classe existentes. Note-se que, neste raciocínio, a distinção

DADOS - Revista de Ciências Sociais, Rio de Janeiro, vol. 61, nº 4, 2018 
entre estratos e classes já não é mais relevante. Isto é, desde que se utilizem classe ou estratos como categorias que definem posições abrangentes na estrutura social com suas respectivas estratégias de "encerramento social" e não apenas como grupos de renda como fazem os estudos de estratificação funcionalistas, é indiferente, do ponto de vista analítico, se nos referimos a classes ou estratos.

Os vínculos entre assimetrias de poder e desigualdades sociais, na linhagem inaugurada por Weber, tem continuidade no trabalho de Elias (2004). Particularmente sugestivo é o modelo da figuração estabelecido-outsider desenvolvido por Elias e Scotson (1994 [1965]) a partir do estudo dos processos de discriminação e estigmatização de novos moradores observados numa pequena cidade suburbana inglesa que recebe o nome, na pesquisa, de Winston Parva. Conforme mostram os dois autores, nesta figuração, isto é, nesta teia de relações de interdependência, os moradores já estabelecidos no local, usando de todos os meios possíveis - da difamação à construção de barreiras de acesso -, buscam alijar os recém-chegados dos espaços sociais e bens públicos e simbólicos disponíveis na comunidade. Relevante para as práticas de exclusão no âmbito desta figuração não são, conforme os autores, marcas culturais ou físicas que diferissem o grupo estabelecido do grupo outsider, mas, sim, as assimetrias de poder que permitiam ao grupo estabelecido o monopólio da significação de traços aparentes, de sorte que as marcas autoadscritas eram decodificadas como símbolos de superioridade e instrumentos de legitimação de vantagens e privilégios. Aos outsiders, por oposição, eram atribuídas marcas de inferioridade que legitimavam seu alijamento do acesso a bens e espaços socialmente valorizados. Ipsis verbis:

"O que encontramos nesta pequena comunidade parece ser uma regularidade universal em qualquer figuração estabelecidos-outsiders: o grupo estabelecido atribuía a seus membros características humanas superiores. O grupo excluía todos os membros do outro grupo de qualquer contato social não profissional com seus membros. Evitar estes contatos era um tabu mantido através do controle social, qual seja, o elogio a quem observava a regra e a difamação pública dos suspeitos de violar o tabu" (Elias e Scotson, 1994 [1965]: xvi)

Entre as contribuições que buscaram combinar as tradições marxista e weberiana para entender o papel das classes na constituição das desigualdades que estruturam as sociedades contemporâneas cabe destaque aos trabalhos de Kreckel (especialmente 1992, 2004) e Therborn 
(especialmente 2013). Kreckel, em sua busca de construir uma sociologia política da desigualdade social, procede, primeiramente, a uma releitura de Weber e Marx, mostrando que há um mal-entendido muito difundido na recepção de Weber, na medida em que se toma os três termos que aparecem no subtítulo $\S 6$ do capítulo VIII de Economia e Sociedade dedicado ao estudo das "Comunidades Políticas". O 6 é intitulado, no original, "Mactverteilung innerhalb der Gemeinschaft: Klassen, Stände, Parteien" (Distribuição de poder no âmbito da comunidade: Classes, Estamentos, Partidos) e é entendido, erroneamente, como a dimensão material (classes), simbólica (grupos de status) e relativa ao poder (partidos) das desigualdades existentes. ${ }^{2}$ Conforme mostra Kreckel (1992:57-63, 69-70), classe corresponde, efetivamente, à dimensão estrutural-material das desigualdades. Contudo, Stände diz respeito, não à dimensão simbólica, mas ao âmbito das interações, relações e redes sociais entre pares, algo próximo a capital social no sentido que lhe confere Pierre Bourdieu (1979). E partidos, por sua vez, não pode corresponder à dimensão do poder já que, na leitura de Weber, o poder não é uma dimensão da desigualdade, mas categoria transversal que perpassa todas as demais dimensões.

Entendendo que a interpretação sociológica representa sempre "um equilíbrio difícil entre generalização e historicização" , Kreckel (1992:76) busca adaptar e expandir ao contexto contemporâneo da Alemanha, ao qual se refere em seus estudos empíricos, as fontes ou vetores da desigualdade social identificados por Marx e Weber. Assim, para responder às necessidades analíticas do capitalismo tardio, Kreckel agrega ao vetor socioeconômico presente tanto em Marx como em Weber, e ao vetor relativo às redes sociais emprestado de Weber, duas novas dimensões da desigualdade, a saber, hierarquia no âmbito de organizações e conhecimento. Kreckel estabelece, assim, uma matriz que comporta quatro vetores de produção das desigualdades verticais nas sociedades contemporâneas, quais sejam: riqueza material, posições em organizações hierárquicas, conhecimento valorizado socialmente, e acesso a associações privilegiadas. No sentido de examinar como as diferentes posições na estrutura social constituídas a partir dos quatro vetores mencionados correlacionam-se com os atores políticos interessados em manter ou transformar um "sistema de desigualdade social específico", Kreckel desenvolve um modelo de campo de forças. Conforme tal modelo, a desigualdade efetivamente observada é resultado das disputas distributivas entre os atores corporativos Estado, capital e trabalho assalariado, através das instituições e orga- 
nizações que os representam. Em torno deste núcleo se posicionam grupos de interesse que representam forças específicas, bem como movimentos sociais. Por fim, "na periferia do campo de forças se encontra a população socialmente estruturada que traduz as condições sociais de desigualdade para a vida cotidiana a partir de valores e potenciais de ação definidos a partir de seu estrato, meio ou condição específica" (Kreckel, 1992:161, grifos acrescentados).

Diferentemente de Kreckel, Therborn (2013) não tem a preocupação de construir uma teoria sistemática sobre classe ou desigualdade. Seu objetivo é investigar as estruturas sociais desiguais como produto das interpenetrações de processos globais e locais. Assim, ele primeiro distingue três dimensões das desigualdades sociais denominadas, respectivamente, desigualdades de recursos, desigualdades vitais e desigualdades existenciais, analisando, em seguida, como estas diferentes formas de desigualdade modificaram-se, recentemente, no plano global. No âmbito desta análise fica, claro, o papel ambivalente desempenhado pelos Estados-nação. Ainda que possam contribuir por meio do fomento de laços de pertença, de impostos e direitos sociais e trabalhistas, para conter o impacto do capitalismo para gerar desigualdades sociais e implodir laços sociais de solidariedade, a concorrência dos Estados nacionais por atrair capitais e investidores vem produzindo, como saldo final, a compressão dos direitos sociais e trabalhistas e o aumento das desigualdades. Além disso, no plano global, os Estados-nacionais contribuem para manter as desigualdades entre cidadãos dos diferentes Estados-nação. ${ }^{3}$ Ipsis verbis:

“[n]o âmbito da globalização pós-1990 [...], a coesão nacional e a igualdade foram achatadas em nome da atratividade nacional para o capital estrangeiro, na China, no Vietnã e também na Argentina, na Europa do Leste e em outras partes. Assim, nações se tornaram territórios dos corpos baratos alcovitados por suas elites para o capital estrangeiro e, desta foram, geradoras sem precedentes de desigualdades sociais. [...] Nações e fronteiras nacionais [...] proveem os governos nacionais alcoviteiros com rendas exorbitantes e constituem as maiores barreiras da exclusão de imigrantes pobres". (Therborn, 2013:175)

Paralelamente a esta mudança no papel dos Estados-nação, Therborn chama a atenção para um desenvolvimento importante na dinâmica global das classes sociais, a saber, a retração, ao menos no plano discursivo, da importância da classe trabalhadora como sujeito coletivo e da generalização dos discursos sobre a classe média. Isto não tem obvia- 
mente nenhuma relação com a hipótese do nivelamento estrutural das desigualdades globais, que são claramente crescentes. Trata-se, na verdade, de discursos ideológicos que caminham, conforme Therborn, em duas direções distintas: o tom sofredor e "lamurioso" da classe média alta norte-americana, a qual teria sido, supostamente, "deixada de lado em vista da ascensão contemporânea da oligarquia do capitalismo financeiro" (ibidem:178), e o discurso das classes médias do Sul global que, inflado pelas agências internacionais e pelas consultorias de empresa, segue pelo caminho oposto, é "exultante, ao relatar a chegada ou a iminente aproximação do Messias no corpo das classes médias consumistas" (idem).

\section{Aproximação à Estrutura Social Brasileira}

Baseando-se no conhecimento legado pela sólida tradição de estudos que analisam a estrutura social brasileira, em parte citados nas páginas abaixo, é possível ajustar e adaptar os postulados analítico-teóricos reconstruídos até aqui e formulados a partir das observações em outros contextos empíricos, de sorte a desenvolver uma matriz compatível com a análise do caso brasileiro. Seguindo este procedimento, cabe, primeiro, identificar os principais vetores que constituem as distâncias ou desigualdades sociais no Brasil. São eles:

1. Riqueza material, incluindo-se aqui patrimônio, meios de produção, rendimentos e outros ativos que, conforme elaborou Kreckel (1992), podem ser convertidos ou ao menos expressos em dinheiro.

2. Posições ocupadas em organizações hierárquicas e espaços valorizados socialmente. O impacto sobre as desigualdades sociais das posições ocupadas por indivíduos em organizações do mundo do trabalho ou de outras esferas da vida social, as quais, seguindo a "ideologia meritocrática" (Kreckel, 1992) estão vinculadas a diferentes níveis de prestígio, poder e compensação, já está bastante estudado e conhecido. ${ }^{4}$ Cabe, contudo, no caso brasileiro, ampliar o alcance deste vetor para que possa abranger espaços sociais organizados hierarquicamente, mesmo que não configurem uma organização. Trata-se, aqui, de espaços de lazer (clubes recreativos, casas de shows etc.), ou mesmo de compras e prestação de serviços (shopping centers, aeroportos) nos quais vigoram critérios discricionários (econômicos ou informais) de acesso (Caldeira, 2014). ${ }^{5}$ Frequentar estes espaços conforma uma dimensão importante da experiência de classe no Brasil. Por decorrência, impedir o acesso

DADOS - Revista de Ciências Sociais, Rio de Janeiro, vol. 61, nº 4, 2018 
de novos aspirantes a tais espaços representa uma forma particular de encerramento social.

3. Conhecimento socialmente valorizado: trata-se de categoria ampla que expressa, conforme mostrou Kreckel (1992), a detenção de capacitações valorizadas e requeridas no capitalismo contemporâneo. De maneira geral, o equivalente geral correspondente a este vetor são os diplomas e títulos. Contudo, é preciso ter em conta que, no caso brasileiro, diplomas e anos de escolaridade não representam equivalentes gerais com consequências imediatas para a mobilidade social. A forte heterogeneidade da qualidade da educação recebida pelos diferentes estratos e classes sociais funciona, na maioria das vezes, como instrumento de encerramento social fazendo com que a escolaridade mais valorizada socialmente recebida pelos mais ricos permita a estes garantir suas altas posições nas hierarquias sociais (ver, entre outros, Quadros, 2008).

4. Acesso a associações exclusivas: esta dimensão é traduzida em diferentes graus de pertença a grupos (étnicos, de gênero, regionais etc.), em geral informalmente estabelecidos, e que garantem vantagens e privilégios a seus membros (Weber, 1956 [1922]; Kreckel, 1992). Para o estudo do caso brasileiro, cabe destacar a existência de ao menos dois tipos de associações informais com enorme impacto para as desigualdades existentes: as alianças informais organizadas por gênero e ou raça que garantem a reprodução das assimetrias em favor dos homens e dos brancos (Costa, 2017) e as associações entre grandes empresas e partidos e políticos individuais com o objetivo de transferir, ilegalmente, recursos do Estado para agentes políticos e econômicos, conforme descrito mais abaixo.

5. Direitos existenciais: este vetor expressa a "alocação desigual da realização pessoal, isto é, da autonomia, da dignidade, dos graus de liberdade e dos direitos de respeito e autodesenvolvimento" (Therborn, 2013:49). No caso brasileiro, a porcentagem significativa da população economicamente ativa alocada no setor informal, sem nenhuma garantia trabalhista, a violação sistemática dos direitos civis de parte da população por agentes estatais e privados e o acesso muito desigual à justiça obrigam a tratar as hierarquias existenciais como uma dimensão própria e fundamental das desigualdades existentes no Brasil. ${ }^{6}$

Pode-se afirmar que as posições ocupadas nas hierarquias relativas a posse ou acesso a cada um dos cinco recursos listados acima definem, 
em linhas gerais, as classes e estratos na estrutura social brasileira, como também grupos razoavelmente nítidos, organizados a partir de categorias etnorraciais e de gênero. ${ }^{7}$ Isto não implica uma completa superposição dos estratos que decorrem dos cinco vetores. Não obstante, a tendência à convergência destes é inegável, de sorte a definir um sistema vertical de estruturação da sociedade razoavelmente consistente no que diz respeito às diferentes dimensões das desigualdades. Assim, os estratos com menos recursos materiais são os que ocupam as posições mais inferiores nas organizações e espaços hierarquicamente organizados. São também os que detêm menos conhecimento socialmente valorizado, menos acesso a associações seletivas e são também os que têm seus direitos existenciais menos protegidos.

Os mecanismos e dinâmicas concretos que levam tanto à perpetuação quanto a deslocamentos e transformações neste sistema de desigualdades verticais no Brasil contemporâneo são seguramente bastante distintos daqueles identificados por Kreckel no seu estudo referente à Alemanha, marcada por um estado de bem-estar social extremamente abrangente e protetor. Não obstante, se aplica ao caso brasileiro, como a outras sociedades capitalistas contemporâneas, a descrição abstrata das disputas distributivas na sociedade alemã oferecida por Kreckel. Isto é, também no Brasil estas disputas se dão num campo de forças compreendendo os três polos corporativos: Estado, capital e trabalho. Institucionalmente, os partidos políticos são os atores principais que conduzem as disputas distributivas. Participam também destas disputas as organizações de interesse legalmente estabelecidas, tais como federações empresariais, centrais sindicais etc. Igualmente relevantes são os grupos de pressão e as redes informais, muitas vezes criminosas, de representantes dos três polos corporativos, com destaque para os vínculos entre atores ligados ao capital e ao Estado. Estes canais são essenciais para a reprodução do sistema de desigualdades, constituindo um mecanismo central das estratégias de encerramento social adotadas pelos mais ricos.

Além dos partidos e organizações empresariais e de trabalhadores, outros atores políticos, como movimentos sociais, organizações não governamentais, meios de comunicação de massa etc., assumem papel fundamental, através de sua atuação no espaço público, na legitimação das desigualdades existentes ou, ao contrário, na justificação e mobilização das lutas para combater as distâncias sociais (Avritzer e Costa, 2004).

DADOS - Revista de Ciências Sociais, Rio de Janeiro, vol. 61, n- 4, 2018 
Igualmente relevante e importante é o papel do contexto internacional nas disputas distributivas entre os polos capital, trabalho e Estado. O tema é seguramente vastíssimo e implica discutir a inserção na economia mundial, já que há evidências, por exemplo, de uma correlação positiva entre produção e exportação de bens primários e níveis de desigualdade (ver, por exemplo, Korzeniewicz e Moran, 2009; ElGindi, 2017). Implica também analisar relações e fluxos externos diversos, desde a transferência internacional de lucros e remessas de imigrantes até acordos de cooperação e convenções internacionais ratificadas por um país específico que, ao inibir, por exemplo, a discriminação de raça ou gênero, apresentam impactos sobre a estrutura social no âmbito nacional. Há que levar em conta também, conforme se mostrou acima, a partir das observações de Therborn, que, com o argumento de criar condições internas mais favoráveis à captação de investimentos estrangeiros, Estados modificam os parâmetros distributivos estabelecidos. Com efeito, através de instrumentos como a renúncia fiscal, supressão de direitos trabalhistas ou subvenções e direitos especiais a investidores, o Estado brasileiro tem fomentado, sistematicamente, a concentração de riqueza e a hierarquia dos direitos no país.

A partir destas considerações pode-se representar o campo de forças entre capital, trabalho assalariado e Estado no Brasil conforme a Figura 1:

\section{A ESTRUTURA SOCIAL BRASILEIRA: TRANSFORMAÇÕES RECENTES}

Durante o primeiro mandato de Luiz Inácio Lula da Silva (2003-2006), inaugura-se o sistema de poder denominado por André Singer (2012) lulismo, e que implicava um pacto de classes, segundo o qual se mantinha uma política econômica ortodoxa com juros altos, câmbio flutuante e orçamento público equilibrado, mas ao mesmo tempo se expandia fortemente os gastos sociais e se elevava o salário mínimo em termos reais na proporção do crescimento econômico alcançado. O pacto de classes deveria garantir ganhos tanto para os mais ricos, que ficavam isentos de aumentos de impostos ou confiscos de bens ou ativos, quanto para os mais pobres, que se beneficiariam dos programas de transferência de renda e do crescimento econômico esperado que lhes renderiam novas oportunidades econômicas. Do ponto de vista político-institucional, o pacto de classes era sustentado pelas alianças do Partido dos Trabalhadores com partidos mais à direita do espectro político. Para formar sua maioria parlamentar, o PT buscou, inicialmente, pagar diretamente aos deputados e senadores pelo apoio ofere- 
Figura 1

Campo de Forças: Capital, Estado, Trabalho no Brasil

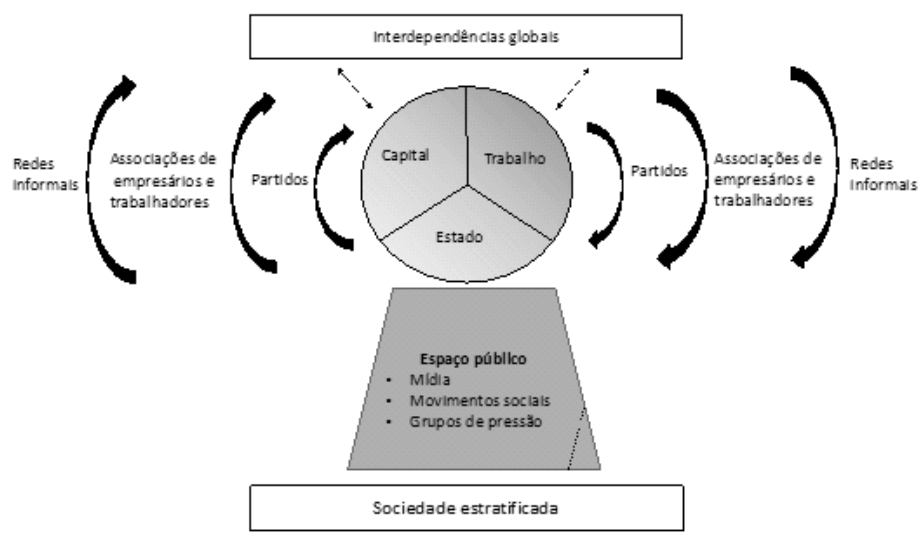

Fonte: Elaboração própria a partir de Kreckel (1992).

cido, no âmbito da prática que ficou conhecida como mensalão. A prática foi, contudo, denunciada em 2005 e os ministros incumbidos de operar o esquema foram exonerados e mais tarde punidos. A alternativa foi então entregar ministérios e cargos a políticos e partidos aliados, em troca do apoio político (Nobre, 2013a). Estas posições são estratégicas não apenas para os partidos alojarem seus quadros e aliados, mas também como instâncias de controle das concessões de contratos públicos e outras vantagens, as quais são usadas como moeda de troca para a negociação de pagamentos ilícitos pelas empresas beneficiadas com o intuito de alimentar os fundos partidários ou o próprio bolso dos políticos envolvidos. Daí serem estas posições conhecidas no vocabulário êmico dos políticos brasileiros como "fabriquinhas" (cf. Franco, 2016).

Este sistema de poder mostrou-se extremamente bem-sucedido, garantindo a reeleição de Lula em 2006, bem como a eleição da então desconhecida sucessora indicada por ele, Dilma Rousseff, em 2010, e sua reeleição em 2014, ainda que, a partir de 2013, os sinais de esgotamento do lulismo já fossem bastante evidentes. Entre 2003 e 2013, o produto interno bruto brasileiro cresceu $64 \%$ e o percentual de pobres na população foi reduzido, conforme as medições baseadas na renda mensal, à metade. Além disso, o gasto social aumentou significativamente, o salário mínimo foi incrementado em $75 \%$ em termos reais e milhões de novas vagas de trabalho formais foram criadas anualmente 
(Bielschowsky, 2014; Pochmann, 2014). Estas mudanças levaram organismos internacionais, como o Banco Mundial (World Bank 2013), o próprio governo brasileiro e mesmo alguns pesquisadores (caso paradigmático: Neri, 2012) a festejar a nova ou emergente classe média brasileira, numa forma muito próxima à dramaturgia messiânica ironizada por Therborn, conforme mostrou-se acima. Alguns cientistas sociais brasileiros criticaram, oportunamente, o entusiasmo apressado com a nova classe média, ao evidenciar os limites conceituais e empíricos do trabalho de Neri e outros que seguiam linha similar de argumentação. Estes autores (entre outros, Xavier Sobrinho, 2011; Scalon e Salata, 2012; Quadros et alii., 2013; Pochmann, 2014) buscam agregar outros indicadores, além da variável renda, ao estudo das transformações na estrutura social observada durante o ciclo do lulismo, fornecendo elementos importantes para entender os deslocamentos observados na pirâmide social brasileira nos anos que antecederam a crise política iniciada em 2013. ${ }^{8}$ A partir destes estudos e de informação estatística, pode-se, efetivamente, encontrar evidências de transformações profundas na estrutura social brasileira, tanto no período 2003-2013, quanto desde então. ${ }^{9}$ Para analisá-las, retoma-se aqui os cinco vetores da desigualdade destacados acima, a saber: riqueza, conhecimento socialmente valorizado, posições em organizações e espaços sociais hierárquicos, associação seletiva e direitos existenciais. $\mathrm{O}$ objetivo não é um estudo minucioso da estrutura social brasileira através da quantificação precisa da mobilidade dos diferentes grupos. $\mathrm{O}$ interesse é identificar tendências de deslocamentos estruturais que, conforme a hipótese adotada, levaram à crise presente. Por isso, não há a preocupação, aqui, em nomear classes ou estratos sociais que cubram toda a população brasileira, mas somente aqueles cuja mobilidade ascendente ou descendente pode ajudar a explicar a crise. Seguindo esta lógica, interessa, particularmente, acompanhar os deslocamentos percorridos por quatro estratos: pobres, outsiders, estabelecidos, e milionários.

\section{Pobres}

Os pobres brasileiros, na acepção aqui adotada, correspondem àquela parte da população que vive no limite da linha de pobreza e que, ou vive de transferências não apresentando rendimentos próprios e/ou ocupa as posições menos valorizadas no mercado de trabalho, com forte participação no trabalho doméstico. É menos escolarizada, não per- 
tence a associações privilegiadas e seus direitos existenciais são particularmente vulneráveis.

Tomando-se o nível de renda, observa-se que a proporção de pobres diminuiu significativamente na década passada. Conforme a apuração da CEPAL (2016:18), 30\% dos domicílios brasileiros, ou 37,5\% da população eram pobres ou indigentes, caindo estes números, respectivamente, para $14,1 \%$ e 16,5\% em 2013. A partir de 2016, o agravamento da crise econômica levou a que o percentual de pobres voltasse nitidamente a crescer (FGV, 2018).

Com relação ao vetor conhecimento, se se toma a variável anos de estudos, há um incremento considerável na situação dos que são considerados pobres e muito pobres nas estatísticas oficiais. Entre 2003 e 2013, se se toma os $40 \%$ mais pobres da população, eles conseguem aumentar em média mais de 1,5 anos seu período médio de estudo, chegando a 5,9 em 2014, enquanto os $20 \%$ mais ricos incrementam cerca de um ano a mais de escolaridade no mesmo período, alcançando, em 2014, 10,8 anos médios de estudo (IBGE, 2015). Como mencionado, a variável anos de estudos pode ser ilusória, na medida em que os mais ricos que frequentam, em geral, o ensino fundamental e o secundário em escolas privadas, e os mais pobres matriculados nas escolas públicas, recebem formação escolar de qualidades muito distintas. Isto explica por que não há uma correlação positiva clara entre o aumento do número de anos de estudo e a conquista de posições mais elevadas no mercado de trabalho, como mostra a decomposição da população por grupos ocupacionais (Quadros, 2008). A partir de 2014, cortes orçamentários verificados nos programas sociais de subsídio aos estudos universitários, especialmente PROUNI e FIES, vêm contribuindo para reduzir matrículas de estudantes mais pobres (INEP, 2018).

Com relação às associações seletivas, não há razões para acreditar que os pobres estabeleceram novas associações privilegiadas no ciclo do lulismo. Não obstante, se tomamos os dados sobre pobreza, verifica-se que sua redução foi ligeiramente maior entre a população negra e entre as mulheres (IPEA, 2015), o que pode indicar uma diminuição do impacto das associações seletivas de brancos e homens sobre as desigualdades.

Com relação aos direitos existenciais, a expansão de programas sociais como os de transferência de renda e programas habitacionais, além do aumento do nível de formalização das relações de trabalho também

DADOS - Revista de Ciências Sociais, Rio de Janeiro, vol. 61, nº 4, 2018 
Sérgio Costa

nos postos menos qualificados do mercado de trabalho, representam uma ampliação considerável dos direitos existenciais dos mais pobres no período que vai até 2013. Mais recentemente, a insegurança com relação à manutenção dos gastos sociais, além do mencionado aumento do desemprego, representam uma ameaça evidente a estes ganhos (FGV, 2018).

\section{Outsiders $^{10}$}

A denominação outsiders não é naturalmente um autoatributo. Ela se enquadra no âmbito da figuração estabelecidos-outsiders descrita acima e expressa a dinâmica que se instaurou quando pessoas, até então classificadas como pobres, ascenderam socialmente, incrementando seu nível de renda e de consumo e passando a disputar espaços sociais e bens de consumo antes reservados aos estabelecidos. As reações dos estabelecidos contempla todo o leque de proteção de privilégios descritos por Elias e Scotson para o caso de Winston Parva: elogio público aos que aceitam a antiga hierarquia, ridicularização e estigmatização pública dos "invasores" por meio de piadas, alcunhas pejorativas etc.

Do ponto de vista da riqueza, salta aos olhos o aumento da renda e da capacidade de consumo dos outsiders ${ }^{11}$ na última década. Conforme as medições de Neri (2012: 27), nada menos que 39,6 milhões deles teriam feito o percurso de pobres a outsiders entre 2003 e 2011. É o poder de consumo deste contingente que explica, em parte, a enorme expansão da venda de bens de consumo duráveis na última década. Desde 2013, contudo, há evidências de que os ganhos econômicos obtidos pelos outsiders encontram-se ainda mais ameaçados que aqueles dos demais grupos aqui considerados, na medida em o aumento das demissões vem afetando este grupo de forma particularmente forte (Barufi, 2016).

Com relação ao conhecimento medido pela escolaridade, há evidências de que os outsiders se beneficiaram, de forma particularmente importante, da vertiginosa expansão do ensino superior verificada desde 2003, quando o número de matrículas nas instituições de ensino superior no Brasil salta de 3,9 milhões para 7,3 milhões (MEC, 2014:26). A ampliação da participação dos outsiders nas universidades se deve, entre outros, ao sistema de cotas introduzido nas universidades públicas e a programas como o PROUNI e o FIES, que oferecem bolsas de estudo ou linhas de crédito para que alunos de menor poder aquisitivo estudem em instituições privadas (Abdal e Navarra, 2014). 
Quando consideramos as posições em espaços sociais hierárquicos como áreas de lazer exclusivas, de consumo e prestação de serviços é evidente que o aumento do poder de consumo dos outsiders leva ao incremento de sua presença nestas áreas antes dominadas pelos estabelecidos. Com sua perda de poder aquisitivo desde 2014, este ganho relativo de posição social fica, contudo, ameaçado.

Com respeito à associação seletiva não há evidências, como no caso dos pobres, que os outsiders lograram criar, nos períodos analisados organizações capazes de garantir-lhes algum privilégio. A redução, contudo, das disparidades de gênero e raça neste segmento evidenciam uma redução do poder das associações seletivas vinculadas à discriminação de gênero ou etnorraciais.

\section{Estabelecidos}

A referência à classe média estabelecida opera como contraparte no âmbito da figuração estabelecidos-outsiders, de sorte a formar uma teia interdependente no sentido definido por Elias. Não é o caso aqui de se definir um intervalo de renda preciso para o grupo dos estabelecidos, já que não é este o critério principal usado para sua definição como classe ou estrato neste texto. Não obstante, com o intuito de avaliar os deslocamentos na estrutura social a partir dos cinco vetores da desigualdade selecionados, pode-se afirmar que este grupo corresponde, no modelo de cinco classes de renda $\mathrm{A}$ a $\mathrm{E}$, àqueles que já se encontravam na classe $C$ em 2003, além dos membros das classes A e B, descontados os milionários, como analisado mais abaixo. Neste grupo heterogêneo, é de se esperar que as disputas no âmbito da figuração estabelecidos-outsiders sejam tão mais acirradas quanto mais próximos os estabelecidos se encontrem dos outsiders na estrutura social. Do ponto de vista da riqueza, se se toma as variáveis renda vê-se que este grupo apresenta ganhos absolutos significativos no período entre 2003 e 2011 (Neri, 2012). Entre 2011 e 2014 há um crescimento do número de brasileiros que pertencem às classes $\mathrm{A}, \mathrm{B}, \mathrm{e} \mathrm{C}$, crescendo também sua participação na renda total. Com relação ao patrimônio e outros ativos, tomando-se os dados das declarações de impostos, há um claro crescimento da riqueza dos grupos de renda média e alta, ao menos nos anos 2006, 2009 e 2012, conforme estudado por Castro (2014).

Com relação à escolaridade, o número médio de anos de estudo para os $40 \%$ mais ricos cresce em cerca de um ano entre 2003 e 2013, alcançando

DADOS - Revista de Ciências Sociais, Rio de Janeiro, vol. 61, n- 4, 2018 
Sérgio Costa

9,4 anos em 2014, um pouco aquém do crescimento dos anos de escolaridade dos pobres e dos outsiders. Particularmente relevante é a participação crescente dos mais pobres entre a população universitária e o decorrente decréscimo da participação proporcional dos estabelecidos neste grupo. Em 2004, a participação dos $20 \%$ mais ricos da população correspondia a $54,5 \%$ das matrículas nas instituições públicas e $68,4 \%$ nas instituições privadas. Em 2014, esta participação passa a 36,4\% e 40,9\%, respectivamente (IBGE, 2015). A partir de 2015, esta tendência é interrompida em razão dos cortes nas políticas específicas, como mencionado acima.

Não há evidências de que os estabelecidos descendam para posições mais inferiores no mercado de trabalho, ao menos no período 2002 e 2009 analisado por Scalon e Salata (2012), já que o maior número de anos de estudo dos mais pobres não havia, ainda, garantido sua ascensão às posições mais altas entre os chamados trabalhadores white color. Não obstante, a perda de posições dos estabelecidos é óbvia em ao menos dois contextos hierárquicos. O primeiro diz respeito aos espaços socialmente segmentados, como shopping centers, aeroportos, espaços de lazer etc., nos quais a presença crescente dos outsiders provocou reações de repulsa e rejeição dos estabelecidos. ${ }^{12}$

A segunda perda de posição para os estabelecidos diz respeito a uma relação laboral específica, qual seja, o trato dos empregados domésticos, que emprega cerca de $7 \%$ de toda a população ocupada no Brasil. No período entre 2003 e 2013, aumenta significativamente a proporção de empregados domésticos com mais de um emprego e torna-se ínfima a proporção daqueles que residem no local de trabalho. A renda dos empregados domésticos, mesmo entre aqueles que só têm um emprego, praticamente duplica no período e há um ligeiro crescimento de trabalhadores com contrato formal de trabalho (IPEA, 2015). Isto implica a paulatina desaparição do modelo da empregada doméstica exclusiva que, sem contrato e horário de trabalho claramente definidos, encontrava-se permanentemente à disposição de quem as empregava. Não poder contar mais com esta prestação de serviço abrangente e a baixíssimo custo representa perda de posição social para as camadas médias e revisões importantes dos arranjos familiares baseados na externalização dos custos da desigualdade de gênero. Ademais, lei em vigência desde 2015 igualou os direitos trabalhistas dos empregados domésticos aos demais trabalhadores, o que implica custos adicionais mensais de $7 \%$ para o empregador. Este custo adicional, associado à 
valorização do salário mínimo, representam uma barreira adicional para os estratos médios contratarem empregados domésticos (Almeida, 2015).

Com relação à associação seletiva, parece razoável considerar que houve, em todo o período, uma redução da eficácia relativa daqueles instrumentos dos quais dispõem os estabelecidos para suas estratégias de encerramento social. Afinal, outsiders, mesmo sendo rechaçados e ridicularizados, lograram um maior acesso a espaços sociais - de universidades a shopping centers - que os estabelecidos entendiam ser de seu uso exclusivo. Finalmente, com relação aos direitos existenciais, se não foram expandidos, tampouco foram explicitamente reduzidos para este grupo no período analisado. É verdade que autopercepções sobre a própria autonomia ou autodesenvolvimento são afetadas, negativamente, pelas restrições a frequentar espaços exclusivos ou contratar uma empregada para cuidar do trabalho doméstico sem qualquer contrato ou garantia. Trata-se aqui, contudo, de perda de privilégios, e não propriamente de direitos.

\section{Milionários}

Há, seguramente, certa arbitrariedade sociológica em tratar os $1 \%$ mais ricos de uma população determinada, como uma classe ou estrato específico, entre quatro grupos considerados. Não obstante, a importância que vêm adquirindo nos debates internacionais sobre desigualdade e a parcela importante da riqueza apropriada por estes $1 \%$ mais ricos no Brasil, além de sua maior resistência a crises, justificam tratá-los como um grupo à parte na estratificação brasileira. A partir dos dados das declarações de renda, Medeiros et alii (2015) concluem que a parcela da renda apropriada pelos $1 \%$ mais ricos, quais sejam, aqueles que ganhavam mais de 203.100,00 reais por ano em 2012 cresceu, recentemente, chegando a $25 \%$ da renda total dos brasileiros em 2012. Partindo também das declarações de impostos de renda, Milá (2015) estuda a evolução da renda do $1 \%$ mais rico no longo prazo, concluindo que esta cai entre 1987 e 2005, mas a partir daí sobe novamente, atingindo, em 2011, seu ápice em toda a série estudada. Não obstante, é razoável supor que estejam perdendo renda, em termos absolutos, no âmbito da presente crise, dada a retração da economia e a redução dos lucros.

Do ponto de vista da riqueza, a concentração é ainda maior e persistente. Castro (2014:103) calcula o índice Gini para o patrimônio e outros 
ativos em 0,860 em 2006, e 0,849 em 2012. Num total de cerca de 25,6 milhões de declarações de impostos entregues no Brasil em 2012, pouco mais de 400 mil declarantes, ou seja, 1,5\% do total de contribuintes declararam patrimônio superior a 1,5 milhão de reais. Estes milionários, correspondendo a $0,2 \%$ da população total, concentravam nada menos que $47 \%$ de toda a riqueza declarada (ibidem).

Entre estes 1\% mais ricos encontram-se empresários que empregam pessoas, mas também rentistas, bem como empregados públicos e empresas privadas, além de pessoas que recebem aposentadorias. Se partimos das variações de escolaridade dos $20 \%$ mais ricos, grupo do qual os milionários fazem parte, pode-se supor que houve um acréscimo de anos de escolaridade em todo o período, ainda que este tenha se mantido ligeiramente abaixo do incremento médio da escolaridade do conjunto dos brasileiros no mesmo período.

Com relação a posições em organizações hierárquicas, há indicações de deslocamentos entre os setores da economia, dada a perda de produtividade da indústria, os ganhos do agronegócio e o incremento dos ganhos do setor financeiro no período 2003-2013. Não obstante, em seu conjunto, a manutenção das posições de prestígio na economia destes $1 \%$ mais ricos permanece inalterada. Mesmo aquela perda de posições que afeta os estabelecidos em espaços sociais hierárquicos não atinge diretamente os milionários, dada a grande distância social e mesmo espacial que os separa dos outsiders. Tampouco as variações no mercado de trabalho doméstico os afeta, uma vez que sua renda mensal média corresponde a quase 100 vezes o salário mínimo.

Com relação à associação seletiva, as investigações correntes sobre corrupção trouxeram à tona os acordos informais e mesmo redes criminosas entre políticos, partidos e grandes empresários sobretudo do setor da construção civil (Anderson, 2016). Este tipo de associação seletiva constituiu estratégia efetiva de encerramento social dos milionários e garantia acesso privilegiado a um restrito grupo da população a fundos públicos. É de se esperar que as investigações tenham ao menos reduzido este tipo de associação seletiva e seu impacto sobre as desigualdades sociais. Por fim, no que diz respeito aos direitos existenciais, não há elementos que indiquem qualquer redução de sua plena vigência para os milionários durante todo o período estudado.

O Quadro 1 abaixo resume os deslocamentos na estrutura social brasileira conforme descritos até aqui: 
Quadro 1

Deslocamentos na Estrutura Social Brasileira, 2003-2013 e desde 2014

\begin{tabular}{|l|c|c|c|c|c|c|c|c|c|c|}
\hline & \multicolumn{2}{|c|}{ Riqueza } & \multicolumn{2}{|c|}{$\begin{array}{c}\text { Posição em } \\
\text { contextos } \\
\text { hierárquicos }\end{array}$} & \multicolumn{2}{c|}{ Conhecimento } & \multicolumn{2}{c|}{$\begin{array}{c}\text { Associação } \\
\text { seletiva }\end{array}$} & \multicolumn{2}{c|}{$\begin{array}{c}\text { Direitos } \\
\text { existencias }\end{array}$} \\
\cline { 2 - 11 } & $2003-13$ & $2014-18$ & $2003-13$ & $2014-18$ & $2003-13$ & $2014-18$ & $2003-13$ & $2014-18$ & $2003-13$ & $2014-18$ \\
\hline Pobres & $\uparrow$ & $\downarrow$ & $\rightarrow$ & $\rightarrow$ & $\uparrow$ & $\downarrow$ & $\rightarrow$ & $\rightarrow$ & $\uparrow$ & $\downarrow$ \\
\hline Outsiders & $\uparrow$ & $\downarrow$ & $\uparrow$ & $\downarrow$ & $\uparrow$ & $\downarrow$ & $\rightarrow$ & $\rightarrow$ & $\uparrow$ & $\downarrow$ \\
\hline $\begin{array}{l}\text { Estabeleci- } \\
\text { dos }\end{array}$ & $\uparrow$ & $\downarrow$ & $\downarrow$ & $\uparrow$ & $\uparrow$ & $\rightarrow$ & $\downarrow$ & $\downarrow$ & $\rightarrow$ & $\rightarrow$ \\
\hline Milionários & $\uparrow$ & $\downarrow$ & $\rightarrow$ & $\rightarrow$ & $\rightarrow$ & $\rightarrow$ & $\rightarrow$ & $\downarrow$ & $\rightarrow$ & $\rightarrow$ \\
\hline
\end{tabular}

Fonte: Elaboração própria.

Legenda: $\uparrow:$ mobilidade ascendente; $\downarrow$ : mobilidade descendente; $\rightarrow$ : estabilidade

\section{CAPITAL, TRABALHO, ESTADO E A CRISE NO BRASIL}

Os movimentos observados na estrutura social brasileira correspondem a deslocamentos no campo de forças entre Estado, capital e trabalho, os quais, por sua vez, refletem relações de dependência e interdependência com o contexto global. Estas interdependências dizem respeito, em primeiro lugar, a fluxos financeiros como investimentos estrangeiros, remessa de lucros ao exterior ou remessa de imigrantes ou de lucros obtidos por empresas brasileiras no estrangeiro. Estes fluxos afetam o montante a ser repartido, alterando a distribuição social tanto entre capital, trabalho e Estado, quanto entre as diferentes classes sociais. Outro componente importante desta interdependência é a inserção brasileira nas cadeias produtivas transnacionais que se modifica substancialmente no período, dada a retração da atividade industrial (Pochmann, 2013). A especialização crescente na exportação de commodities fez com que a queda persistente no preço internacional das matérias primas não apenas levasse a economia à recessão, mas também alterasse os parâmetros da distribuição interna da renda e da riqueza. Da mesma forma, tendências globais em um determinado setor da economia, como a abrangente terceirização no setor bancário, modificam, dramaticamente, a margem de manobra das negociações distributivas no âmbito nacional, como mostra Sproll (2013).

No plano político, a retórica amigável ao capital, tanto nacional quanto estrangeiro, adotada pelo governo brasileiro em todo o período estudado implicou restrições à política econômica e à adoção de medidas

DADOS - Revista de Ciências Sociais, Rio de Janeiro, vol. 61, n- 4, 2018 
redistributivas mais radicais, de sorte a manter a chamada "confiança dos mercados". Ao mesmo tempo, convenções do direito internacional ratificadas pelo governo brasileiro e mesmo a transnacionalização de movimentos sociais observada neste período influenciaram o jogo distributivo nacional em favor de estratos e grupos menos privilegiados, como foi o caso de mulheres e negros (Gonçalves e Costa, 2016).

Se considerarmos a distribuição de recursos entre os polos capital, trabalho, Estado, há, no período considerado, um aumento da participação do Estado na distribuição geral da renda. A receita tributária passa de 31,4\% do PIB em 2003 para 33,5\% em 2014 (Ministério do Planejamento, 2015). Quando se observa a composição da carga tributária, contudo, as assimetrias de poder entre os três polos corporativos ficam bastante evidentes. Em contraste com países com melhor distribuição de renda que tributam ganhos do capital em até $42 \%$, no Brasil, lucros e dividendos são isentados do imposto de renda. Os tributos sobre salários, representando $26,5 \%$ do total, e sobre o consumo de bens e serviços, representando $49,7 \%$, formam o grosso da arrecadação tributária (Castro, 2014:25, dados de 2012). Isto é, se é verdade que os governos comandados pelo PT aumentaram os gastos com políticas sociais, contribuindo assim para combater a pobreza, do ponto de vista da arrecadação não houve mudanças no modelo apoiado nos impostos indiretos, os quais são regressivos, isto é, promovem concentração de renda. No período aqui estudado não houve nenhum movimento organizado ou discussão sistemática no espaço público brasileiro sobre as consequências distributivas desta estrutura tributária.

Lula foi eleito presidente em 2002 com um programa de governo que enfatizava o combate à desigualdade (PT, 2002), obtendo uma votação bem distribuída no território nacional e entre os diferentes grupos de renda com um expressivo apoio nas cidades maiores e nos grupos mais escolarizados, bases eleitorais históricas do PT. Já a partir de sua reeleição em 2006 se inicia uma tendência que se aprofundaria na eleição de Dilma Rousseff em 2010 e sua reeleição em 2014. Desde então, a base eleitoral principal de Lula e depois de sua sucessora Rousseff vai se descolocando cada vez mais para os grupos mais pobres, movendo-se do Sudeste para o Nordeste do país e das cidades maiores para as menores. $\mathrm{O}$ discurso do partido também se modificou. A menção à redistribuição da riqueza não desaparece completamente dos programas eleitorais, mas vai perdendo a centralidade para a ampliação do consumo e para a ênfase na mobilidade social individual e na expan- 
são da classe média. Isto aparece de forma lapidar no programa de governo de Dilma Rousseff apresentado na campanha eleitoral de 2014:

"Nas três primeiras gestões petistas, os governantes, junto com os partidos aliados, tomaram a decisão política de reconhecer direitos que até então eram subtraídos da imensa maioria da população: morar, comer, estudar, ter acesso a serviços de saúde, ao saneamento básico, à casa própria, ao emprego e a um patamar mínimo de renda para ter uma vida digna. Ao mudar as condições de vida desse enorme contingente de pessoas, trouxe-os à esfera pública, conscientes de seus direitos. São eles que ingressam no mercado de trabalho mais instruídos que a mão de obra anterior; que conseguem chegar à faculdade como os primeiros dentro de seus núcleos familiares; que pressionam o poder público com demandas por mais serviços e de melhor qualidade. [...]. Para os cidadãos brasileiros, o necessário para o futuro mudou porque o patamar de exigências passou a ser outro: não querem mais o mínimo necessário para viver, mas o máximo possível para que mantenham o seu poder de consumo e possam acenar para seus filhos com vidas melhores que as deles". (PT, 2014, grifos suprimidos)

A adesão ao discurso que elogia a "nova classe média" por Lula e, com mais ênfase, por Rousseff, vai ficando evidente não apenas nos momentos eleitorais. Passou a integrar as declarações públicas cotidianas destes governantes e orienta mesmo atos da Presidência da República que, através da Secretaria de Assuntos Estratégicos, cria, em 2011, uma "Comissão para a Definição da Classe Média no Brasil". Em seu relatório final, a Comissão (2012:7) busca estabelecer o que entende ser "uma definição conceitualmente sólida, prática e de fácil compreensão desse grupo, para que a qualidade de vida da nova classe média possa ser continuamente monitorada e sua presença e aspirações possam ser incorporadas ao desenho, implantação e operacionalização das políticas públicas".

Ao lado do comprometimento político com a "nova classe média", fica explícito no discurso dos presidentes e em muitas de suas ações de governo, o compromisso de combater a discriminação de raça e gênero. Assim, criam-se, já em 2003, primeiro ano de governo de Lula, secretarias especiais com status de ministério para se dedicar a políticas para a mulher e para a promoção da igualdade racial (Costa, 2015).

Este conjunto de discursos e ações passa a ser significado, no plano político, como uma ameaça aos estabelecidos. As perdas não são econô-

DADOS - Revista de Ciências Sociais, Rio de Janeiro, vol. 61, no 4, 2018 
micas já que, conforme se mostrou, os estabelecidos aumentam sua renda e riqueza no período que vai de 2003 a 2013. São perdas de posição em contextos hierárquicos e perda de eficácia de suas associações seletivas para garantir suas estratégias de encerramento social. Desde muito cedo, alguns meios de comunicação passam a vocalizar o temor dos estabelecidos, construindo o discurso da classe média "lamuriosa" em oposição aos discursos ufanistas sobre os outsiders.

Este tipo de discurso, que combina a defesa da posição de classe dos estabelecidos com a descredibilização do combate à discriminação de gênero e raça, vai se cristalizando, ao longo dos anos, como um discurso antipetista. Afinal, o partido e muitos de seus representantes, entre eles, seu líder mais importante, Lula, corporificam, com sua presença nos espaços sociais e políticos antes reservados aos estabelecidos, a "invasão" dos outsiders em pessoa. Ainda que o discurso lamurioso dos estabelecidos acompanhe todo o período em que o PT ocupa o governo, seu poder de mobilização e articulação de parcelas mais representativas da sociedade permanece reduzido enquanto a economia brasileira crescia a taxas aceleradas e os pobres, os outsiders e os milionários viam sua condição material e social melhorar. Igualmente marginal permaneciam as críticas opostas ao PT, vocalizadas por intelectuais de esquerda e movimentos sociais, os quais faziam objeções aos limites da política redistributiva adotadas e aos excessos do modelo econômico pouco sustentável com suas consequências danosas para o meio ambiente, as "populações tradicionais" e para a qualidade de vida nas cidades.

Estes discursos críticos vão adquirindo, contudo, ressonância pública na segunda metade do primeiro mandato de Dilma Rousseff e alimentam, a partir de junho de 2013, uma série de protestos públicos com marchas e passeatas em várias cidades brasileiras (Nobre, 2013b; Gohn, 2014; Santos e Swako, 2016). Os protestos se iniciam com um movimento pela gratuidade do transporte público para estudantes, portanto, como um movimento de esquerda interessado em ampliar o estado de bem-estar, mas vão crescendo e incorporando as insatisfações mais generalizadas com o governo Dilma Rousseff. Pouco a pouco, movimentos mais à direita no espectro político passam a convocar e dirigir as manifestações que, apesar de adotar um tom generalizado de crítica à política institucionalizada, vão se tornando cada vez mais nitidamente um protesto contra o governo e o Partido dos Trabalhadores, em geral. 
No âmbito parlamentar, a aliança com o PMDB, além de outros partidos menores, que havia garantido ao PT até 2014 sua base parlamentar, perde sua sustentação desde então, dada a abrangente investida contra a corrupção, combinando ações do Judiciário, Ministério Público e a Polícia Federal. Além de impedir ou, ao menos, limitar o acesso de políticos e partidos aos canais de geração dos recursos ilícitos que alimentavam seus cofres, a investida gera pânico entre os políticos e empresários envolvidos pelo temor de serem descobertos e presos, como aconteceu em vários casos. As investigações, ao desarticular as bases de sustentação parlamentar de Rousseff, acabam levando a seu afastamento em 2016 e à ascensão de Michel Temer ao poder, apoiado, em grande medida, pela mesma base parlamentar que havia dado sustentação aos governos comandados pelo PT. Fica evidente, na mudança de governo, o interesse dos parlamentares de buscarem, na transição, a tábua de salvação para seus mandatos e, na medida do possível, a recuperação de suas "fabriquinhas" (Santos e Swako, 2016).

No âmbito do espaço público, mudanças importantes também ocorreram. A partir do final de 2015, em vista do agravamento da crise econômica, entidades empresariais, lideradas pela Federação das Indústrias do Estado de São Paulo (FIESP), entram na disputa política em favor da destituição de Rousseff. Na mesma ocasião, à medida que a possibilidade do impeachment vai ficando mais iminente, movimentos sociais e intelectuais que, nos anos anteriores, haviam se distanciado do PT, se rearticulam contra a deposição da presidente. Depois que Temer assume, definitivamente, a presidência, estes grupos passaram a denunciar sua falta de legitimidade e combater as medidas por ele adotadas, as quais tiveram, claramente, o sentido de reverter, ou ao menos paralisar, os deslocamentos na estrutura social em favor dos outsiders e pobres, observados no ciclo anterior. Exemplos claros de medidas desta natureza foram o congelamento dos gastos sociais por 20 anos, aprovado em 2016, e que afeta muito mais duramente os mais pobres que dependem mais diretamente dos serviços públicos, bem como a proposta de reforma da Previdência, em tramitação, que aprofunda as desigualdades sociais e de gênero (ANFIP/DIEESE, 2017). Analisadas a partir do campo de forças entre capital, Estado e trabalho, o conjunto das medidas adotadas, as quais incluem novas privatizações e concessões de serviços a agentes privados, apresentam o sentido claro de deslocar o arranjo distributivo em favor do capital em detrimento do trabalho assalariado. O programa de governo do presidente eleito, Bolsonaro, ao insistir na redução de direitos sociais e numa reforma tributária clara- 
Sérgio Costa

mente regressiva, tem o sentido óbvio de dar continuidade à redistribuição às avessas iniciada por Temer, isto é, retira dos que têm menos para dar aos que têm mais.

\section{CONCLUSÕES}

Ao definir as classes sociais a partir de uma perspectiva multidimensional, trabalhos que buscam combinar as tradições marxista e weberiana na análise da estrutura social representam uma contribuição indispensável para a compreensão dos conflitos distributivos nas sociedades contemporâneas. Orientando-se em trabalhos que combinam estas duas tradições analíticas, o presente texto buscou estudar a crise política brasileira contemporânea como conflito distributivo, envolvendo quatro classes ou estratos (pobres, outsiders, estabelecidos, e milionários) definidos a partir de cinco vetores determinantes da desigualdade social: riqueza, posição, conhecimento, associação seletiva e direitos existenciais. A definição destas classes ou estratos considerou não a posição ocupada na estrutura social num determinado momento, mas a trajetória social percorrida por cada grupo desde 2003.

Em linhas gerais, as quatro classes ou estratos considerados viram sua riqueza e seu conhecimento crescer no período entre 2003 e 2013. Seus direitos existenciais cresceram ou, ao menos, mantiveram-se estáveis neste período. Com relação à posição e à associação seletiva, o movimento observado entre 2003 e 2013 é bastante distinto para as diferentes classes. Enquanto os outsiders ascendem significativamente de posição social, os estabelecidos perdem posição social na medida em que diminui seu poder de excluir outsiders de espaços sociais, antes de uso exclusivo seu. A mesma lógica se aplica para a associação seletiva referida a gênero e raça. Mesmo que a igualdade de gênero e etnorracial esteja longe de ser alcançada no Brasil, há, entre 2003 e 2013, uma diminuição do poder de homens e brancos de discriminar mulheres e negros. Esta perda de posições nas hierarquias de classe, gênero e raça alimenta o ressentimento dos estabelecidos contra o governo do PT mesmo nos tempos em que, em termos de riqueza, encontravam-se em trajetória ascendente.

A partir de 2014, o quadro se modifica. A agudização da crise econômica faz com que todos os grupos, com especial ênfase nos outsiders, percam riqueza. O corte de vagas de trabalho no mercado formal produz a perda de direitos existenciais, sobretudo, para os pobres e os outsiders. 
Os estabelecidos, mesmo que se tornem menos ameaçados pelos outsiders, também decaem socialmente, na medida em que a recessão avança. Por fim, os milionários, que até então haviam ganhado em todos os níveis da desigualdade durante os governos do PT, perdem ao menos parte de suas associações seletivas na medida em que as investigações de corrupção avançam e suas redes criminosas com o Estado e com a política são desmanteladas. Neste momento, os milionários, através de suas entidades representativas com a FIESP, começam a exigir, publicamente, a destituição da presidente Rousseff. A impressão que fica é que os estabelecidos, dada a ressonância de suas posições e opiniões nos meios de comunicação de massa, constituem um ator decisivo para influenciar a opinião pública. Contudo, a formação da vontade política, no sentido da aglutinação de decisões com efeito vinculante, é ainda dependente dos ânimos dos milionários. Quando entenderam que os interesses do capital se encontravam ameaçados e seus canais privilegiados de acesso ao Estado foram obstruídos, eles entraram na luta política que se desenrolava na esfera pública, decidindo o jogo a seu favor. Neste sentido, pode-se interpretar as medidas adotadas pelo governo Temer que assume o poder em 2016 como uma resposta, antes de tudo, ao anseio de recuperação das perdas dos milionários. Estas medidas indicavam um esforço de promover um rearranjo distributivo que aumentasse o quinhão do capital e reduzisse a porção do produto interno apropriada pelo trabalho assalariado. A prolongada recessão e as dificuldades institucionais e públicas enfrentadas pelo governo Temer para conter as investigações sobre corrupção impuseram limites à reconfiguração do arranjo distributivo pretendida. A aposta no presidente recém-eleito, Bolsonaro, aparece, neste contexto, como tentativa de aprofundar o rearranjo distributivo iniciado por Temer em benefício do capital, dos homens brancos, dos milionários e da classe média estabelecida.

(Recebido para publicação em 28 de julho de 2016)

(Reapresentado em 05 de abril de 2017)

(Aprovado para publicação em 14 de dezembro de 2018)

DADOS - Revista de Ciências Sociais, Rio de Janeiro, vol. 61, n- 4, 2018 


\section{Sérgio Costa}

\section{NOTAS}

1. Todas as citações de obras publicadas em outras línguas foram traduzidas pelo autor para o português.

2. O mesmo equívoco se dá no capítulo IV "Stände und Klassen", traduzido equivocamente para o inglês como "status groups and classes". A tradução espanhola publicada no México pela Editora Fondo de Cultura Económica pela primeira vez 1944 é fiel ao original e traduz Stände como estamentos. Contudo, na recepção contemporânea de Weber no Brasil, muito influenciada pela bibliografia americana, comete-se frequentemente o equívoco de tomar Stände por grupos de status.

3. A operação da cidadania como instrumento de encerramento social de cidadãos dos países mais ricos e que tem como consequência a reprodução as desigualdades entre os membros dos diferentes Estados nacionais é desenvolvida de forma muito elucidativa por Boatcã (2015:177 ss).

4. No Brasil cabe destaque ao trabalho de Scalon que, num artigo instigante e sem precedentes na bibliografia brasileira, refaz as linhagens neomarxistas e neoweberianas da análise de classes, concluindo que: "Ao buscar traduzir essas teorias em classificações direcionadas à aplicação empírica, Wright e Goldthorpe acabam por destacar certas características ocupacionais que estruturam seus esquemas de classes: propriedade, qualificação, treinamento, recursos organizacionais, autonomia e controle sobre o próprio trabalho e o trabalho de outros, rendimento e status de emprego" (Scalon 1998: 346 grifos meus). A autora adota estas características em sua própria análise "sempre que os dados permitirem tais distinções" (ibidem). Ainda que considerar estas características seja fundamental para os estudos de mobilidade social, elas se restringem à esfera ocupacional e não abrangem o conjunto de variáveis necessárias a uma sociologia política das desigualdades sociais buscada aqui.

5. As hierarquias sociais são refletidas e reproduzidas nestes espaços de maneiras diversas: na arquitetura que muitas vezes dificulta o acesso a quem não usa automóvel ou que assegura mais conforto e agilidade no atendimento de quem paga mais, na vigilância ostensiva de "intrusos" definidos por critérios de aparência e etnorraciais etc. Vários estudos de caso baseados em etnografia ou análise de discurso mostram como operam estas hierarquias, como é o caso de pesquisa conduzida por Nascimento et alii em Belo Horizonte: "Os resultados demonstram o sentido simbólico do shopping como espaço de segregação social, que implicitamente deveria ser restrito a apenas determinada parcela da sociedade para ser considerado um espaço valorizado, seguro e que conferiria distinção social" (2015:260).

6. A rigor, seria necessário incluir uma sexta dimensão da desigualdade à uma análise compreensiva da estrutura social brasileira, qual seja, a dimensão ecológica. A expansão da produção de commodities, no período estudado, criou novos riscos e danos ambientais para a população rural, enquanto o drástico aumento do número de automóveis e motocicletas circulando nas cidades deteriorou a qualidade de vida urbana, afetando de maneira muito desigual as diferentes classes sociais. Opta-se por não levar em conta esta dimensão no presente ensaio dadas as dificuldades de estimativa de seu impacto sobre a estrutura social.

7. Parte da literatura sobre desigualdades sociais distingue entre desigualdade vertical, como aquela referente à distribuição da população por classes ou estratos, e desi- 
gualdade horizontal, referida às desigualdades entre grupos organizados conforme gênero ou sexo, etnicidade, raça ou outra variável relevante (Stewart 2000). As desigualdades observadas no Brasil entre homens e mulheres, de um lado, e negros e brancos, de outro, são, contudo, de tal forma nítidas, duradouras e generalizadas que me parece mais adequado considerar três níveis ou eixos complementares das assimetrias sociais verticais: classes ou estratos, sexo ou gênero, raça ou cor da pele. As desigualdades regionais no país e entre residentes no campo e na cidade são igualmente expressivas. Trata-se, contudo, de desigualdades espacializadas que não podem ser integradas, como variável à parte, na análise da estrutura social nacional.

8. Salata (2015) procura aprofundar a crítica ao conceito de classe de Neri, mostrando que falta a devida correspondência entre posição de classe e identidade de classe. Isto é, a "classe C", a "nova classe média", não incorporaria a identidade que lhe caberia como classe média, nem é reconhecida pelo restante da população como tal. A despeito da qualidade técnica insofismável da pesquisa de Salata, o trabalho apresenta pressupostos muito problemáticos. Do ponto de vista teórico, transformar classe, categoria analítica útil para estudar desigualdades, num sujeito virtual no âmbito de uma teoria da ação, ou seja, estabelecer uma correspondência entre posição de classe e um comportamento cultural ou político que dela decorre, é algo questionado desde Weber, como referido acima. Empiricamente, o uso de surveys para estudar supostas identidades de classes é inadequado, na medida em que estas identificações não são preferências ou autoclassificações pré-políticas captáveis por um questionário. Estas identificações se formam (se é que se formam) em interações e situações concretas no âmbito do jogo político, as quais só podem ser apreendidas e reconstruídas a partir do uso de metodologias qualitativas como observação participante, etnografias etc.

9. Boa parte das fontes secundárias consultadas usa como unidade de análise para estudar as mudanças na estrutura social não indivíduos, mas famílias, o que permite captar o papel das famílias na reprodução da desigualdade social. Não obstante, a informação sobre famílias tende a invisibilizar o "gap" de gênero. Além dos censos demográficos que têm a desvantagem de serem decenais e apresentarem longo tempo de processamento, os estudos sobre desigualdade no Brasil se valem basicamente das informações coletadas pelo Instituto Brasileiro de Geografia e Estatística através das Pesquisas Nacionais por Amostra de Domícilios (PNADs) de periodicidade anual, e do microcenso POF, Pesquisas de Orçamento Familiar com resultados divulgados até o momento para dois períodos 2002-2003, 2008-2009. Mais recentemente, a base de dados da Receita Federal, reunindo todas as declarações de imposto de renda dos brasileiros passou a ser contemplada nos estudos sobre desigualdade e progressividade tributária (Castro, 2014). Os dados de impostos são, sobretudo, indicados para aferir a concentração de renda no topo da pirâmide social, a qual aparece subestimada nas amostragens por domicílio.

10. Em artigo muito sugestivo, Arretche (2018) utiliza a expressão outsiders para se referir a grupos que estiveram tradicionalmente excluídos das políticas sociais. $\mathrm{O}$ uso que venho fazendo do termo é distinto, na medida em que remeto à análise das tensões entre outsiders e estabelecidos, no âmbito da teoria da figuração de Elias (ver Costa, 2016).

DADOS - Revista de Ciências Sociais, Rio de Janeiro, vol. 61, nº 4, 2018 


\section{Sérgio Costa}

11. O potencial de consumo é alimentado, em boa medida, pela ampliação do crédito gravado com taxas de juros reais muito acima dos parâmetros internacionais, o que leva a um crescente endividamento das famílias (Lavinas, 2016).

12. Um caso de "ridicularização pública" que poderia ser anedótico, mas que se tornou paradigmático pela repercussão pública que obteve na mídia e nas redes sociais ocorreu em 2014 quando uma professora universitária postou em seu Facebook a foto de um homem que, soube-se depois, era procurador público, e que estava vestido de camiseta regata e bermuda na sala de embarque do Aeroporto Santos Dumont, no Rio de Janeiro, com a seguinte legenda: “Aeroporto ou rodoviária?" Entre os muitos posts que compartilhavam a indignação da professora apareciam: "O glamour de voar definitivamente se foi". "Isso é só uma amostra do que tenho visto pelo Brasil" (Toledo, 2014:2). 


\section{REFERÊNCIAS BIBLIOGRÁFICAS}

ABDAL, Alexandre e NAVARRA, Julia. (2014), “Uni por uni, eu escolhi a que era do lado da minha casa: deslocamentos cotidianos e o acesso, a permanência e a fruição da universidade por bolsistas do Prouni no ensino superior privado". Novos Estudos, no 99 , p. 65-87.

ALMEIDA, Marili. (2015), "Como a Nova Lei dos Empregados Domésticos Pesa no Bolso". Exame.com, 29/09/2015. Disponível em: http:/ / exame.abril.com.br/seu-dinheiro/noticias / como-a-nova-lei-dos-trabalhadores-domesticos-pesa-no-bolso. Acesso 10 de março de 2017).

ANDERSON, Perry. (2016), "Crisis in Brazil". London Review of Books, vol. 38, no 8, pp. $15-22$.

ANFIP / DIEESE (2017): Previdência: reformar para excluir? Contribuição técnica ao debate sobre a reforma da previdência social brasileira. Brasília: ANFIP - Associação Nacional dos Auditores Fiscais da Receita Federal do Brasil e Dieese - Departamento Intersindical de Estatística e Estudos Socioeconômicos

ARRETCHE, Marta. (2018), "Democracia e Redução da Desigualdade Econômica no Brasil. A Inclusão dos Outsiders.". Revista Brasileira de Ciências Sociais, vol. 33, no 96, pp. $1-23$.

AVRITZER, Leonardo e COSTA, Sergio. (2004), “Teoria Crítica, Democracia e Esfera Pública: Concepções e Usos na América Latina". DADOS - Revista de Ciências Sociais, vol. 47, no 4, pp. 703-728.

BARUFI, Ana Maria (2016). “Movimento Recente de Retorno para as Classes D e E parece ser Conjuntural". Destaque Depec. Bradesco, Ano XII (133), 1-3.

BIELSCHOWSKY, Ricardo. (2014), “O Modelo de Desenvolvimento Proposto por Lula e Dilma”. Brasil Debate. <http://brasildebate.com.br/o-modelo-de-desenvolvimento-proposto-por-lula-e-dilma>.

BOATC_, Manuela. (2015), Global Inequalities Beyond Occidentalism. Farnham, Ashgate.

BOURDIEU, Pierre. (1979), La Distinction. Critique Sociale du Jugement. Paris, Les Éditions de Minuit.

CALDEIRA, Teresa. (2014), “Qual a Novidade dos Rolezinhos? Espaço Público, Desigualdade e Mudança em São Paulo". Novos Estudos, no 104, pp. 13-20.

CASTRO, Fábio Ávila de. (2014), Imposto de Renda da Pessoa Física: Comparações Internacionais. Medidas de Progressividade e Redistribuição. Dissertação de Mestrado, Brasília, Universidade de Brasília.

CEPAL. (2016), Panorama Social de América Latina. Santiago do Chile, CEPAL.

COSTA, Sérgio. (2015), "Protection without Redistribution? Conceptual Limitations of Policies Meant to Reduce Inequalities Concerning Race and Gender in Brazil", in B. Fritz e L. Lavinas (eds.). A Moment of Equality for Latin America? Challenges for Redistribution. Farnham, Ashgate, pp. 235-252.

. (2016), Millionaires, the Established, Outsiders and the Precariat. Social Structure and Political Crisis in Brazil. Working Paper 99, desiguALdades.net. Disponível em:

DADOS - Revista de Ciências Sociais, Rio de Janeiro, vol. 61, nº 4, 2018 


\section{Sérgio Costa}

<http://www.desigualdades.net/Resources/Working_Paper/WP-99-Costa-Online.pdf $>$.

. (2017), “Dilemmas of Inter-American Anti-Racism. Re-Visiting ‘On the Cunning of Imperialist Reason'”, in W. Raussert (ed.). The Routledge Companion to Inter-American Studies. Londres, Routledge, pp. 338-349.

DAVIS, Kingsley e MOORE, Wilbert. (1944), "Some Principles of Stratification". American Sociological Review, vol. 10, no 2, pp. 242-249.

ELIAS, Norbert. (2004), Was ist Soziologie?. Weinheim, Juventa.

e SCOTSON, John. (1994 [1965]), The Established and the Outsiders. Dublin, University College Dublin Press.

ELGINDI, Tamer. (2017), "Natural Resource Dependency, Neoliberal Globalization, and Income Inequality: Are they Related? A Longitudinal Study of Developing Countries (1980-2010)". Current Sociology, vol. 65, no 1, pp. 21-53.

FGV. (2018), “Qual foi o Impacto da Crise sobre a Pobreza e a Distribuição de Renda?”. Rio de Janeiro, Fundação Getulio Vargas Social. Disponível em: $<$ https://cps.fgv.br/Pobreza_Desigualdade>.

FRANCO, Bernardo M. (2016), “Ponte para o Futuro”. Folha de S. Paulo, 02 de agosto, p. 2.

GOHN, Maria da G. (2014), As Manifestações de Junho de 2013 no Brasil e Praças dos Indignados no Mundo. Petrópolis, Vozes.

GONÇALVES, Guilherme L. e COSTA, Sérgio. (2016), “The Global Constitutionalization of Human Rights: Overcoming Contemporary Injustices or Juridifying Old Asymmetries?". Current Sociology, no 64, pp. 311-331.

IBGE. (2015), Pesquisa Nacional por Amostra de Domicílios 2014. Rio de Janeiro, Instituto Brasileiro de Geografia e Estatística. Disponível em: <http://www.ibge.gov.br/ home/estatistica/populacao/trabalhoerendimento/pnad2014/>. Acesso em $15 \mathrm{ju}$ nho 2016.

IBGE. (2016), Pesquisa Nacional por Amostra de Domicílios 2015. Rio de Janeiro, Instituto Brasileiro de Geografia e Estatística. Disponível em: <http://www.ibge.gov.br/ home/estatistica/populacao/trabalhoerendimento/pnad2015/default.shtm>.

INEP. (2018), Sinopses Estatísticas da Educação Superior - Graduação 2017. Brasília, Instituto Nacional de Estudos e Pesquisas Educacionais Anísio Teixeira. Disponível em: $<$ http:/ / portal.inep.gov.br/web/guest/sinopses-estatisticas-da-educacao-superior $>$.

IPEA. (2015): Retrato das desigualdades de Raça e Gênero. Brasília, Instituto de Pesquisas Econômicas Aplicadas. Atualizações disponíveis em: <http://www.ipea.gov.br/retrato/>.

KORZENIEWICZ, Roberto Patricio e MORAN, Timothy Patrick (2009), Unveiling Inequality. Nova York, Russell Sage Foundation.

KRECKEL, Reinhard (1992), Politische Soziologie der sozialen Ungleichheit, Frankfurt a. M., Campus.

(2004), Politische Soziologie der sozialen Ungleichheit. 3a ed. revista e ampliada. Frankfurt a. M., Campus 
LAVINAS, Lena. (2016), 21st Century Welfare. New Left Review, no 84, pp. 5-40.

MEC. (2014), A Democratização e Expansão da Educação Superior no País 2003-2014. Brasília, Ministério da Educação.

MEDEIROS, Marcelo et alii. (2015), “O Topo da distribuição de renda no Brasil: Primeiras estimativas com dados tributários e comparação com pesquisas domiciliares, 2006-2012", DADOS - Revista de Ciências Sociais, vol. 58, no 1, pp. 7-36.

MILÁ, Marc M. (2015), Income Concentration in a Context of Late Development: An Investigation of Top Incomes in Brazil using Tax Records, 1933-2013. Tese de Mestrado, Paris, School of Economics.

MINISTÉRIO DO PLANEJAMENTO. (2015), Evolução Recente da Carga Tributária Federal. Brasília, Assessoria Econômica do Ministério do Planejamento, Orçamento e Gestão.

NASCIMENTO, Marco C. et alii. (2015), “Com que Cor Eu Vou pro Shopping que Você me Convidou?”. RAC-Revista de Administração Contemporânea, vol. 19, no3, pp. 245-268.

NERI, Marcelo. (2012), A Nova Classe Média. O Lado Brilhante da Base da Pirâmide. São Paulo, Saraiva.

NOBRE, Marcos. (2013a), Imobilismo em Movimento. Da Redemocratização ao Governo Dilma. São Paulo, Companhia das Letras.

. (2013b), Choque de Democracia: Razões da Revolta. São Paulo, Companhia das Letras (E-Book).

PARKIN, Frank. (1972), Class Equality \& Political Order. Frogmore: Paladin.

. (1974), "Strategies of Social Closure in Class Formation", in F. Parkin (ed.). The Social Analysis of Class Structure. Londres, Tavistock, pp. 1-18.

POCHMANN, Marcio. (2013), “Mobilidade Social no Capitalismo e Redivisão Internacional da Classe Média", in D. Bartelt (ed.). A "Nova Classe Média" no Brasil como Conceito e Projeto Político. Rio de Janeiro, Fundação Heinrich Böll, pp. 156-171.

. (2014), O Mito da Grande Classe Média: Capitalismo e Estrutura Social. São Paulo, Boitempo Editorial.

QUADROS, Waldir. (2008), A Evolução Recente da Estrutura Social Brasileira. Campinas, Textos para Discussão IE/UNICAMP 48.

et alii. (2013), "Classes medias e as desigualdades sociais no Brasil”, in D. Bartelt (ed.). A "nova classe média" no Brasil como Conceito e Projeto Político. Rio de Janeiro, Fundação Heinrich Böll, pp. 43-55.

SAAD-FILHO, Alfredo. (2015): "Watch Out for Judicial Coup in Brazil”, MR Zine, online at ((last access 22 August 2016): http://mrzine.monthlyreview.org/2016/ sf230316.html

SALATA, André (2015): “Quem é Classe Média no Brasil? Um Estudo sobre Identidades de Classe". Dados, vol. 58, no 1, pp. 111-149.

SANTOS, Fabiano e SWAKO, José. (2016), “Da Ruptura à Reconstrução Democrática no Brasil". Saúde Debate, no 40, número especial, pp. 114-121.

SCALON, Maria Celi. (1998). "Mapeando Estratos: Critérios para Escolha de uma Classificação." Dados, vol. 41 no. 2, 337-375

DADOS - Revista de Ciências Sociais, Rio de Janeiro, vol. 61, nº 4, 2018 


\section{Sérgio Costa}

SCALON, Celi e SALATA, André. (2012), “Uma Nova Classe Média no Brasil da Última Década? O Debate a partir da Perspectiva Sociológica". Sociedade e Estado, vol. 27, no 2, pp. 387-407.

SINGER, André. (2012), Os Sentidos do Lulismo: Reforma Gradual e Pacto Conservador. São Paulo, Companhia das Letras.

SPROLL, Martina. (2013), Precarization, Genderization and Neotaylorist Work: How Global Value Chain Restructuring Affects Banking Sector Workers in Brazil. Working Paper 44. Berlim, desiguALdades.net.

STEWART, Frances (2000), “Crisis Prevention: Tackling Horizontal Inequalities”. Oxford Development Studies, vol. 28, no. 3, pp- 245-262.

THERBORN, Göran. (2013), The Killing Fields of Inequality. Cambridge, Polity Press.

TOLEDO, José Roberto de. (2014), “Aeroporto ou Rodoviária?”. O Estado de S. Paulo, 10 fev., p. 5.

WEBER, Max. (1956 [1922]), Wirtschaft und Gesellschaft. Grundriss der verstehenden Soziologie. 4 a ed. Tübingen, J. C. B. Mohr.

WORLD BANK. (2013), Economic Mobility and the Rise of the Latin American Middle Class. Washington, World Bank.

WRIGHT, Erik Olin (1985), Classes. Londres, Verso.

XAVIER SOBRINHO, Guilherme. (2011), “A ‘Classe C' e sua Alardeada Ascensão: Nova? Classe? Média?". Indicadores Econômicos FEE, vol. 38, no 4, pp. 67-80. 
RESUMO

Estrutura Social e Crise Política no Brasil

Orientando-se em trabalhos que combinam as tradições marxista e weberiana na análise da estrutura social, o texto estuda a crise brasileira contemporânea como conflito distributivo, envolvendo quatro classes ou estratos (pobres, outsiders, estabelecidos, milionários) definidos a partir de cinco vetores determinantes da desigualdade social: riqueza, posição em contextos hierárquicos, conhecimento, associação seletiva e direitos existenciais. A hipótese orientadora é que a aliança de classes comandada pelo PT trouxe, entre 2003 e 2013, em geral, mais riqueza, conhecimento e direitos existenciais, mas perda de posição para os estabelecidos já que seu poder de excluir outsiders e pobres diminui. A partir de 2014, a crise econômica faz com que todos os grupos percam riqueza, ainda que em proporções distintas. Ao mesmo tempo, as investigações sobre corrupção desarticulam as associações seletivas dos milionários com políticos e o estado. Diante deste quadro, o arranjo distributivo entre capital, trabalho assalariado e estado estabelecido pelo PT em 2003 (o "lulismo") perde sua sustentação na esfera pública e no âmbito parlamentar, culminando com o afastamento de Rousseff. Seu sucessor, Temer, reajustou, sistematicamente, o arranjo distributivo em favor do capital. O novo governo conduzido pelo político de extrema direita Bolsonaro segue na mesma linha.

Palavras-chave: estrutura social, crise política, impeachment no Brasil

\section{ABSTRACT}

\section{Social Structure and Political Crisis in Brazil}

Focusing on works that combine Marxist and Weberian traditions in the analysis of social structure, this article addresses the present-day Brazilian crisis as a distributive conflict, involving four social classes or strata (the poor, outsiders, the well-to-do, and millionaires) defined from five determinant vectors of social inequality: wealth, position in hierarchical contexts, knowledge, selective association and existential rights. The guiding hypothesis is that the PT-led alliance between 2003 and 2013 was able to increase the overall level of wealth, knowledge and existential rights, but the established lost positions given their diminished capacity to exclude outsiders and the poor. Starting in 2014, the economic crisis caused all groups to lose wealth, albeit in different proportions. At the same time, investigations of corruption threw the selective associations between millionaires, politicians and the state in disarray. In view of this situation, the distributive arrangement among capital, wage labor and the state established by the PT in 2003 lost its support in the public sphere and at the parliamentary level, culminating in the removal of Dilma Rousseff. The adjustments introduced by Temer have so far had the clear sense of reforming the distributive arrangement in favor of the upper strata.

Key words: social structure, Political crisis, impeachment, PT, Lulismo

DADOS - Revista de Ciências Sociais, Rio de Janeiro, vol. 61, nº 4, 2018 
Sérgio Costa

RÉSUMÉ

Structure Sociale et Crise Politique au Brésil

Orienté sur des œuvres combinant les traditions marxiste et weberienne dans l'analyse de la structure sociale, le texte étudie la crise brésilienne contemporaine en tant que conflit distributif, impliquant quatre classes ou strates (pauvres, étrangers, établis, millionnaires) définies à partir de cinq vecteurs déterminants des inégalités sociales: richesse, position dans des contextes hiérarchiques, savoir, association sélective et droits existentiels. L'hypothèse de base est que l'alliance des classes de PT entre 2003 et 2013 a généralement apporté plus de richesse, de connaissances et de droits existentiels, mais une perte de position pour les établis concernemant son pouvoir d'exclure les outsiders et de faibles diminutions. Depuis 2014, la crise économique entraîne une perte de richesse pour tous les groupes, même dans des proportions différentes. Dans le même temps, les enquêtes sur la corruption désorganisent les associations sélectives de millionnaires avec les politiciens et l'État. Face à cette situation, le dispositif de répartition entre capital, travail salarié et État mis en place par le PT en 2003 ("lulismo") perd son soutien dans la sphère publique et dans la sphère parlementaire, aboutissant au départ de Rousseff. Temer, a systématiquement réajusté l'arrangement distributive en faveur du capital. Le nouveau gouvernement dirigé par le politicien d'extrême droite Bolsonaro a adopté un programme similaire.

Mots-clés: structure sociale, crise politique, impeachment au Brésil

\section{RESUMEN}

\section{Estructura Social y Crisis Politica en Brasil}

Ubicado en el cruce de análisis marxistas y weberianos, el artículo analiza la crisis contemporánea brasileña como un conflicto distributivo, involucrando cuatro clases o estratos - pobres, outsiders, establecidos, millonarios. Dichos estratos son, a su vez, definidos con base a cinco vectores determinantes de desigualdad: riqueza, posición en contextos jerárquicos, conocimiento, asociación selectiva y derechos existenciales. Nuestra hipótesis sostiene que la alianza de clases coordinada por el PT (del 2003 hasta 2013) ha traído, en general, más riqueza, conocimiento y derechos existenciales. Sin embargo, ha traído pérdida de posición para los establecidos, pues que su poder de excluir a los outsiders y pobres disminuye. Desde el 2014, la crisis económica hace que todos los grupos pierdan riqueza, aunque en proporciones distintas. Al mismo tiempo, las investigaciones sobre corrupción desarticulan a las asociaciones 
selectivas de los millonarios con políticos y el Estado. Así, el arreglo distributivo entre capital, trabajo asalariado y Estado conformado por el PT (el llamado 'lulismo') pierde su fundamentación en la esfera pública y en el ámbito parlamentario, culminando con el impeachment de D. Rousseff. Su sucesor, Temer, reajustó sistemáticamente el arreglo distributivo a favor del capital. El nuevo gobierno conducido por el político de extrema derecha Bolsonaro ha adoptado un programa similar.

Palabras clave: estructura social, crisis política, impeachment. 